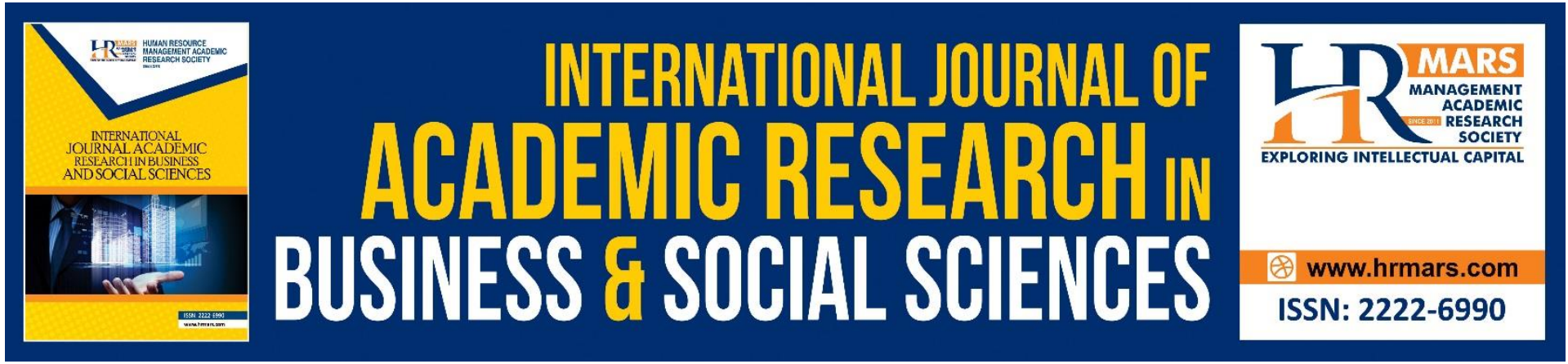

\title{
Determinants of Consumer Perceived Trustworthiness in Digital Advertising of Food and Beverage
}

Shathees Baskaran, Leong Chin Gan, Kesavan Nallaluthan, Logaiswari Indiran, Ma Kalthum Ishak \& Teh Zaharah Yaacob

To Link this Article: http://dx.doi.org/10.6007/IJARBSS/v11-i8/10536

DOI:10.6007/IJARBSS/v11-i8/10536

Received: 04 June 2021, Revised: 30 June 2021, Accepted: 18 July 2021

Published Online: 01 August 2021

In-Text Citation: (Baskaran et al., 2021)

To Cite this Article: Baskaran, S., Gan, L. C., Nallaluthan, K., Indiran, L., Ishak, M. K., \& Yaacob, T. Z. (2021). Determinants of Consumer Perceived Trustworthiness in Digital Advertising of Food and Beverage. International Journal of Academic Research in Business and Social Sciences, 11(8), 60-77.

Copyright: (c) 2021 The Author(s)

Published by Human Resource Management Academic Research Society (www.hrmars.com)

This article is published under the Creative Commons Attribution (CC BY 4.0) license. Anyone may reproduce, distribute, translate and create derivative works of this article (for both commercial and non-commercial purposes), subject to full attribution to the original publication and authors. The full terms of this license may be seen at: http://creativecommons.org/licences/by/4.0/legalcode

Vol. 11, No. 8, 2021, Pg. 60 - 77

http://hrmars.com/index.php/pages/detail/IJARBSS

JOURNAL HOMEPAGE

Full Terms \& Conditions of access and use can be found at http://hrmars.com/index.php/pages/detail/publication-ethics 


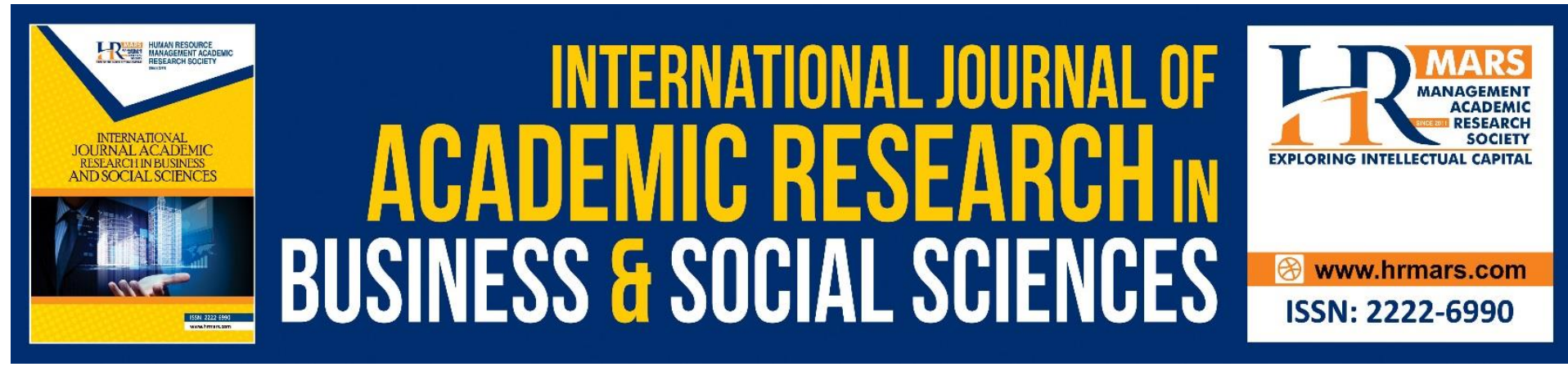

\title{
Determinants of Consumer Perceived Trustworthiness in Digital Advertising of Food and Beverage
}

\author{
Shathees Baskaran, Leong Chin Gan, Kesavan Nallaluthan, \\ Logaiswari Indiran, Ma Kalthum Ishak \& Teh Zaharah Yaacob \\ Azman Hashim International Business School, Universiti Teknologi Malaysia, Faculty of \\ Management \& Economics, Universiti Pendidikan Sultan Idris
}

\begin{abstract}
The advertising industry has been moving toward digital advertising with the help of internet penetration across the world. Importantly, consumers today are exposed to digital advertising with social media advertising becoming one of the most vital channels to get in touch with the consumers. However, consumer trust in social media is reported to be low although trust is not a static concept but changes over time. Hence, this research aimed to study the relationship between social media advertising and consumer perceived trustworthiness among social media users in Malaysia. Consumers' perceived trustworthiness is examined through five dimensions of social media advertising namely personalization, electronic wordof-mouth, interactivity, informativeness, and trendiness. The research employed a quantitative research method and resulted in 415 valid respondents. The statistical results indicated that all dimensions of social media advertising have a significant relationship with consumer perceived trustworthiness. In particular, informativeness, personalization, and electronic word-of-mouth were found to have a stronger association with consumer perceived trustworthiness. These findings added to the existing marketing literature and provided valuable insights for marketers on the ways to enhance consumer perceived trustworthiness through various dimensions of social media advertising. Practically, this study will help the food and beverage industry to understand dominant factors that create consumer trustworthiness while designing their social media marketing interventions to maximize the effect of advertising to survive in a fast-changing and competitive business environment.

Keywords: Interactivity, Informativeness, Personalization, Trendiness, Electronic Word of Mouth, Trustworthiness.
\end{abstract}

\section{Introduction}

The interest in food has been on an increasing trend among consumers. This positive signal for food demand has encouraged the food and beverage organizations to embrace social media to reach out to the consumers through various communication tools including audio and visuals. When compared to previous kinds of advertising and marketing, most firms and organizations are nowadays depending on digital advertising and marketing tactics (Ali Taha 
et al., 2021). The rising population of social media users has made social media advertising to be one of the vital channels for food and beverage organizations to get in touch with the consumers. Many major and small businesses use publicly available social media channels to engage in communications in the struggle to stay competitive and relevant (Susanto et al., 2021). A survey conducted in 2018 indicated that on average, every Malaysian spend 2 hours and 58 minutes on social media (Wanxiang, 2019). The social media adoption rate is expected to continue to grow and generation $\mathrm{Z}$ will be the main proportion of social media users in near future, where they account for 29.7 percent of the Malaysian total population (Emran \& Rahim, 2016). Making social media marketing an integral part of business strategy produces many benefits (Shareef et al., 2019; Shiau et al., 2017) apart from allowing an organization to achieve its marketing objectives (Ajina, 2019) by adapting to the changing behaviors of the consumers(Stephen \& Lehmann, 2016). It is the main intention of food and beverage organizations to connect with the customers and to build an ultimate food experience. Social media has been proven to have capabilities in connecting the consumers through product and service brands by influencing their attitudes, and eventually improving organizational performance (Algharabat et al., 2018; Kapoor et al., 2018; Kaur et al., 2018; Lal et al., 2020). While the boom of social media has come as a positive sign to the growth of the food and beverage industry, there are constant challenges posed in managing the business. One of the main challenges revolves around consumer's trustworthiness of the food and beverage served, especially in the context of online businesses. The issue of trustworthiness continuing to be a central focus on social media advertising (Kowang et al., 2018).

Kumar and Pradhan (2018) reported that consumer trust in social media is currently low and it is not a static concept but changes over time hence trust management is becoming vital in social media marketing for organizations. A study by Meskaran (2015) further revealed that perceived trustworthiness has a significant direct effect on the online purchase intention of the consumers. More specifically, Samat et al (2014) found that trustworthiness influences one's attitude towards social media advertising before making purchase decisions. Besides, a consumer who is uncomfortable with the ways social media advertising is used by marketers may develop negative attitudes leading to loss of trust and affects their relationship with the organization which in turn affects their purchase decisions (Arnold, 2018; Goldfarb \& Tucker, 2013). In contradiction, some authors reported that the trustworthiness of social media advertising is viewed as the least important consideration, especially among youngsters. Nevertheless, in the same year, Xiao et al (2018) and a year later, Balaban and Mustățea (2019) found that trustworthiness is a significant cue in social media marketing. A recent study posited that the impact of social media as a marketing channel for food-related items is minimal (Bermoy et al., 2021) which also adds to existing debates. This unending argument has prompted paramount attention towards the perceived trustworthiness of social media marketing. As a result, figuring out what elements impact people's perceptions of trustworthiness has become a hot topic in academia (Wijenayake et al., 2020). Hence, it has become vital to continuously investigate the determinants of trust among consumers (LunaNevarez \& Torres, 2015), especially in a social media marketing-oriented business environment that is understudied (Wang et al., 2016) and suffered lack of testable hypotheses (Knoll, 2016).

Despite multiple challenges in the industry, restoration of consumer trustworthiness lies in the ability of the food and beverage industry to identify areas of concern so that they are surmountable by embracing the changes through careful and proactive planning and execution of social media marketing. Unlocking these concerns and acting to address them 
will enable the organizations within the food and beverage industry to navigate the challenges and capitalize on opportunities. Given the contradicting findings in the literature, there is a need for developing a more granular understanding of consumers' trust towards social media advertising. Hence, this study aims to discuss the determinants of consumers' perceived trustworthiness and to provide theoretical and practical contributions about key aspects of social media marketing within the food and beverage context while advancing the knowledge within the marketing domain. It is a timely addition to the marketing literature as the consumers are maturing and social media advertising taking a center stage in the business strategy formulation of the organizations.

\section{Literature Review}

\section{Consumer Perceived Trustworthiness}

Trust can be described as "the willingness to be vulnerable to the actions of another party based on the expectation that the other will perform a particular action important to the trustor, irrespective of the ability to monitor or control that other party" (Mayer et al., 1995). Trust involves buyer-seller relationships (Büttner \& Göritz, 2008) and psychologically, the trust would decline when the positive expectations are disconfirmed (Lewicki et al., 2006). Trustworthiness on the other hand is the degree of confidence in the content that shares are valid claims according to Ohanian's study (Ohanian, 1991). Trustworthiness is also viewed as constantly deliver the promised (Erdem \& Swait, 2004) failing which will have an advertising effect on consumers. Additionally, according to Jarvenpaa et al (2000), the trustworthiness of customers towards online vendors reflects the extent to which the customer trusts their online vendors in their willingness to buy (McCole et al., 2010) that influencing buying decisions. The strong foundation of trust development leads to the trustworthiness of consumers towards the organization driven by emotional or sentimental attachments (Kumar \& Pradhan, 2018). Consumers who search for information on multiple social media platforms perceive the information obtained as more trustworthy than the traditional communication channels alone (Mangold \& Faulds, 2009; Vollmer \& Precourt, 2008).

\section{Social Media Advertising}

Social media is a common term today as it links people across the world. Moreover, social media is also a platform used to share information. Social Media Advertising on the other hand is a platform that lets the users reciprocate user-generated content on the internet-based platform such as blogs, wikis, Instagram, Facebook, Twitter, and YouTube (Kaplan \& Haenlein, 2010). It is an instrument for business owners to enhance value through marketing activities as part of their marketing strategy (Pham \& Gammoh, 2015). The emerging trend in business is social media marketing, and this study can assist entrepreneurs and business owners in improving their marketing methods (Bermoy et al., 2021). So social media advertising will have the power to influence consumers. Social media advertising can be a 2-edged sword. It can allow users to comment freely on the platform boosting the brand or spoiling, spamming, or damaging the brand intentionally. The consumer's behavior shift has led the advertising industry to adapt to the consumer's behavior changes, and start shifting their marketing strategy from traditional media to digital media. This has provided the marketer with a good opportunity to reach a broader range of consumers since there is a growing trend of social media adoption that enables the generation of an individual relationship with the users (Kelly et al., 2010). This also has allowed the marketer to change the way brand content is shaped, circulated, and consumed. The effectiveness of any media plan is determined by how 
successfully the advertising strategy is implemented while keeping the target audience in mind (Gupta \& Maheshwari, 2021). A review of social media advertising indicated that several dimensions often characterize it.

\section{Interactivity}

Interactivity is defined as a relationship between two parties, where it can be people or objects. Interactivity is an activity that involves interaction, frequently involved with many previous messages or experiences. So, it can also be explained as the extent to which communication reflects on itself, feeds on, and responds to the past (Newhagen \& Rafaeli, 1996). According to the social media integration theory, higher interactivity on the post will generate higher exposure in social media. From a marketing perspective, interactivity is explained as the degree of Social Media Advertising to provide a group or platform for its consumers to share content and feedback (Yadav \& Rahman, 2018). It allows the company to gain insight into consumer satisfaction through the comment and feedback shared on social media. While interactivity can be distinguished from different perspectives consist of the type of communication and formal property (Downes \& McMillan, 2000). The formal property perspective which refers to a media technology is a measure of a media's ability to let the users influence the content and/or form of the mediated communication (Toscan, 1999).

\section{Informativeness}

Informativeness is referred to the degree to which the social media platform delivers valuable, accurate, and comprehensive info. The subjective evaluation of users as to whether the information matches their demands and intended usage will determine the informativeness quality (Jiang et al., 2021). Based on the study conducted previously, 63 percent of millennials like and follow the brand on Facebook (Yadav \& Rahman, 2018). Cognitive Learning Theory (Nicosia, 1966) confirmed that consumers tend to analyses the information in an advertisement through personal understanding. Additionally, the consumers are also predicted to trust the information shared on official pages, as it provides official, legitimate, and comprehensive information. Previous researchers found that the credibility and reliability of the advertisement possibly are subject to the argument and counterargument in the advertising statement (Kim \& Ko, 2010). Regardless of traditional or online advertisement, Informativeness plays an important role to create consumers' positive perceptions towards the advertisement (Shareef et al., 2019). Therefore, the informativeness of the advertisement content plays a very vital part in being persuasive. The information on the media platform is among other factors that affect the consumer's perceived value and credibility of the advertisement.

\section{Personalization}

Personalization refers to the degree of the social media custom-made service to fulfill the requirement of a consumer. (Kettinger \& Lee, 1994) explained that personalization is about providing information that individualized attention to users' perceptions. Online behavioral targeting in advertising is commonly used in social media advertising, which is advertised based on user purchase and search history. Usually, it will follow the users across multiple platforms, from web browsers to social media platforms. Such moves are a two-edge sword marketing strategy. On one hand, it will increase the exposure while on the other hand, it might create irritation on the users as well (Hassan et al., 2013). Nevertheless, some researchers (Goodwin, 1996; Mittal \& Lassar, 1996) indicated that such personalization 
services by the organizations allow users to focus consideration on the subject of interest and filter the subject that is not related to the consumer's interest. The positive findings of personalization research postulate that personalized content to consumers' specific interests creates positive user attitudes toward the media, which leads to better satisfaction and create higher user engagement (Erat et al., 2006; Kettinger \& Lee, 1994; Prahalad \& Ramaswamy, 2004). This can be attributed to the relevance of the personalized content that motivates user engagement for quality social interaction (Parasuraman et al., 1991; Prahalad \& Ramaswamy, 2004).

\section{Trendiness}

Social media is a platform able to offer the newest topics and is heavily discussed in news (Naaman et al., 2011). One of such topics includes the trendiness of consumers. Trendiness is referred to the degree of social media advertising's ability to provide trendy content. The trendiness can also be considered as a propagation or spread of the latest and trendy information (Godey et al., 2016). The implantation of trendiness is very common in social media advertising. It is often used to generate the viral effect in social media where the organizations can make use of the viral effect to promote the company, and the attractiveness of the post will have a positive influence on the consumers' attitude (Lim et al., 2017).

\section{Electronic Word of Mouth}

Consumers tend to look for information and comment when making a purchase decision. Therefore, Electronic Word-of-Mouth (eWOM) has a high influence on consumer perception and purchase intention. eWOM refers to the degree to which social media user recommends and share experience on a platform. The eWOM activity in social media can be classified into three perspectives: opinion seeking, opinion passing, and opinion giving (Chu \& Kim, 2011). Social media has created a perfect environment for consumers to generate and share eWOM about products or services related information to their connection in social media without restriction (Kim \& Ko, 2010; Vollmer \& Precourt, 2008). Research provided empirical evidence that eWoM has a positive and significant association with consumer's perceived brand image and social media trustworthiness (Yunus et al., 2016). Hence, organizations use eWOM as an alternative medium to promote their good and services. Muntinga et al. (2011) posited that eWOM is beneficial to the organization because it involves an online consumer to consumers sharing about the brands and products that are indirect marketing to an organization. While interactivity, informativeness, personalization, and trendiness are internally planned and executed by the organizations, eWOM is a mediator that mediates the internal marketing plans of the organization.

\section{Research Model and Hypotheses}

Social media has become an important area for many advertisers as it provides new opportunities to organizations (Lakshmanan \& Basariya, 2017). The emergence and rise of social media reshaped the communication channels and captured the attention of various parties including organizations and customers in confronting different types of challenges arising from changes to consumer behaviours and consumption patterns. More importantly, Mir (2012) highlighted the influence of social media advertising on consumer attitudes and their behaviour of clicking favourable advertisements. This is one of the many ways organizations pursue to persuade customers to buy the products being advertised. Hence, it 
is evident that social media advertising will have the power to impact the consumers' response to the product and eventually affect purchase intention (Hutter et al., 2013; Kim \& Ko, 2010). Interactivity is widely acknowledged as an essential component of the communication process and as a relational maintenance technique that leads to relational outcomes (Ariel \& Avidar, 2015). Past research has shown that a high level of perceived interactivity will encourage attitudes towards the advertisement on social media (Yaakop et al., 2013). Besides, Hadija (2008) found that perceived interactivity to be a significant factor influencing consumer responses toward social media advertising. Therefore, it was hypothesized that interactivity in social media advertising is positively associated with consumer perceived trustworthiness. Consequently, it is hereby hypothesized that:

H1: There is a significant relationship between interactivity and consumer perceived trustworthiness.

Credible and complete information shared by the organizations enables consumers to make informed decisions in making their decisions. Consumers are likely to receive the information through the intended meaning of the statement (Ertmer \& Newby, 1993). Consumers tend to digest information in an advertisement through personal perception. Therefore, informativeness in social media advertising plays a key part in persuading and influence consumers perceived trustworthiness. It was found that consumers' positive perceptions towards the advertisement have been proven in all types of advertisement communications including traditional media as well as online media (Shareef et al., 2019). On the grounds of these discussions, it is therefore hypothesized that:

H2: There is a significant relationship between informativeness and consumer perceived trustworthiness

Social media users tend to have positive attitudes toward personalized content and it leads to higher engagement and better satisfaction in social media advertising. This was evident in many researches since the last three decades (Erat et al., 2006; Kettinger \& Lee, 1994; Prahalad \& Ramaswamy, 2004). It is also argued that the key factor that drives higher user engagement is the quality of the social interaction, where the content shared to use is relevant instead of the frequency of the interactions (Parasuraman et al., 1991; Prahalad \& Ramaswamy, 2004). Understanding consumer behavior allows organizations to ensure that personalized advertisements are populated while the consumers are on social media. Such personalization tackles the interest of the customers and such personalized advertisements are influencing consumer decisions. Hence, it was hypothesized that:

H3: There is a significant relationship between personalization and consumer perceived trustworthiness.

Trendiness is another aspect of online advertisements that has gained wide attention in the past. Generally, trendiness is associated with younger people who are very concerned and very positive about it (Auty \& Elliott, 1998). Trendiness which is complemented with viral effect creates attractiveness to the advertisement and eventually result in a positive effect on the consumer's attitude (Lim et al., 2017). When organizations are aware of current trends and tailor suit their online advertisements to match these trends, their online marketing strategies often have an enhanced impact in attracting customers who are active users of social media. Therefore, it was hypothesized that: 
H4: There is a significant relationship between trendiness and consumer perceived trustworthiness.

Electronic Word of Mouth (eWoM) relates to any positive or negative statements by former, current, and potential customers about an organization's product and/or services. It is usergenerated content over digital marketing platforms. Muntinga et al (2011) clarified that social media view eWOM as an online consumer to consumers sharing about the brands or products. Nevertheless, eWOM may overlap to include viral marketing to engage the customers in communication processes that influence consumers buying decisions. eWOM may become a viral component if the message being communicated is sufficiently persuasive (Estrella-Ramón \& Ellis-Chadwick, 2017). Yunus et al (2016) explained that eWOM positively and significantly affects the consumer's perceived brand image and social media trustworthiness. In this vein, various researches have emphasized the importance of eWOM in creating trustworthiness among consumers. It is envisaged that a positive word of mouth is expected to enhance trustworthiness while negative views will affect the impact of social media marketing activities. Therefore, it was hypothesized that there is a significant positive relationship between eWoM and consumer perceived trustworthiness in social media advertising.

H5: There is a significant relationship between the Electronic Word of mouth and consumer perceived trustworthiness.

The present study is underpinned by two prominent theories in understanding consumers, namely the Uses and Gratifications Theory and Theory of Reasoned Action. These theories in general address the consumers' trust and attitudes toward social media marketing (Xu-Priour et al., 2014). Plume and Slade (2018) explained that the Uses and Gratifications Theory is one of the noticeable and mainstream theories that discover the motivations of a consumer in determining the attitudinal and behavioral outcomes. This universality allows the research to be applied to investigate various scenarios. Besides, this theory is also used to explain the reasons for users selecting a particular media of their choice against all other available media (Dolan et al., 2016). The use of Uses and Gratifications Theory has evolved over the years (Hossain, 2019; Mishra, 2019; Zong et al., 2019) from traditional forms (e.g. newspaper, telephone, radio, etc.) to other areas of research in understanding the media users' interest (Corkindale et al., 2018; Thongsri et al., 2018). While the Theory of Reasoned Action has a similar focus as of Uses and Gratifications Theory to understand trust, behavior, and attitude of consumers (Xu-Priour et al., 2014), the Theory of Reasoned Action becomes influential in discovering insights from a technical use perspective of consumers (Nwagwu \& Famiyesin, 2016). Underpinned by these two theories, Figure 1 shows the proposed framework for this research. 


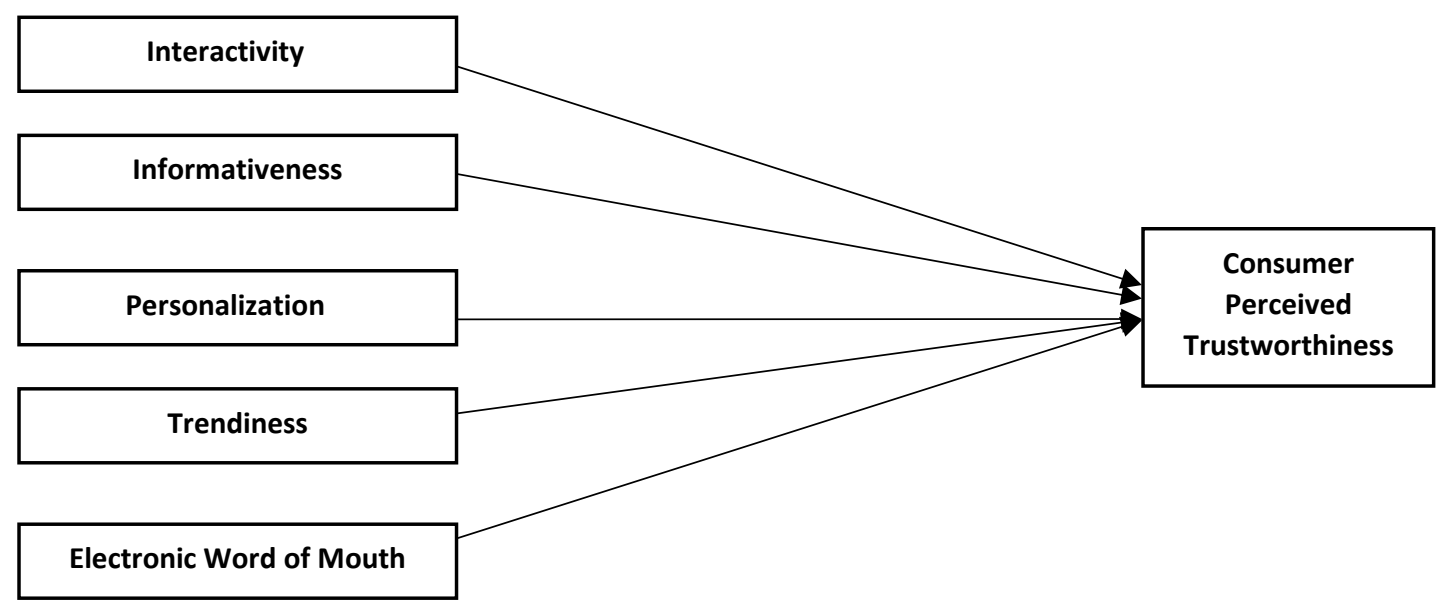

Figure $1 \quad$ Research Model

\section{Methodology}

\section{Sample and Data Collection}

The sampling framework will be used in this research according to Kothari et al. (1997), an optimum sample size that is big enough to provide the desired confidence interval and should not be too small that may create unfairness toward the research result. This research will study social media platform users in Malaysia by focusing on the food and beverage industry. An estimated 24.6 million social media users in Malaysia. According to Krejcie and Morgan's Table, with a 95\% confidence level and 5\% margin error, the total sampling size was 384 respondents for more than 1 million population. This research employed a convenience sampling technique, it will be collecting data in a large population and it provides convenient and cost-effective ways to collect data.

\section{Measures and Instrumentation}

The Likert scale is commonly used in social sciences research. 5-point Likert scale will be used, 1 indicating strongly disagree to 5 indicating strongly agree. To conduct the research, validated instruments were adopted from previous research to measure the consumer perception of social media advertising activities (Yadav \& Rahman, 2018). On the other hand, the instrument for the perceived trustworthiness of online shops was adopted from McKnight et al. (1998). Table 1 shows a summary of the research instruments and items.

Table 1Research Test Instruments

\begin{tabular}{|c|c|c|}
\hline Author(s) & Construct/Dimension & $\begin{array}{l}\text { Number } \\
\text { of Items }\end{array}$ \\
\hline Yadav and Rahman & Interactivity (INT) & 3 \\
\hline (2018) & Informativeness (INF) & 3 \\
\hline & Personalization (PER) & 3 \\
\hline & Trendiness (TRE) & 3 \\
\hline & Electronic Word of Mouth (EWM) & 3 \\
\hline McKnight et al. (1998) & $\begin{array}{ll}\text { Consumer } & \text { Perceived } \\
\text { Trustworthiness (CPT) } & \end{array}$ & 9 \\
\hline
\end{tabular}




\section{Results}

\section{Research Sample Analysis}

A useable 415 responses were received from the survey conducted. In terms of gender, both males and females participated in almost an equal proportion. As indicated earlier discussions, respondents from the age group of 18 to 25 years old made up $55 \%$ of the total respondents.

Table 2Research Sample Analysis

\begin{tabular}{llll}
\hline Demography & Category & Frequency & $\%$ \\
\hline Gender & Male & 200 & $48 \%$ \\
& Female & 215 & $52 \%$ \\
\hline Age & 18 to 25 years old & 229 & $55 \%$ \\
& 26 to 35 years old & 134 & $31 \%$ \\
& 36 to 45 years old & 40 & $10 \%$ \\
& 46 to 55 years old & 11 & $3 \%$ \\
& 56 years old and above & 1 & $1 \%$ \\
\hline \multirow{2}{*}{ Status } & Employed & 183 & $44 \%$ \\
& Self-employed & 22 & $5 \%$ \\
& Student & 196 & $47 \%$ \\
& Unemployed & 14 & $4 \%$ \\
\hline
\end{tabular}

\section{Sample Adequacy}

Sample adequacy is used to inspect the adequacy of the sample and the appropriateness of data for Factor Analysis (Burton \& Mazerolle, 2011). Kaiser-Meyer-Olkin (KMO) (Kaiser, 1960) was used to quantify and examine the sampling adequacy. KMO can range between 0 and 1 , while 0.50 is considered appropriate for subsequent analysis (Hair et al., 1998). On the other hand, Bartlett's Test of Sphericity (Bartlett, 1950) requires that the approximate chi-square value be significant $(p<0.5)$.

Table 3. Sampling Adequacy

\begin{tabular}{lll}
\hline KMO and Bartlett's Test & & \\
\hline Kaiser-Meyer-Olkin Measure of Sampling Adequacy.0.866 \\
\hline Bartlett's Test of Sphericity & Approx. Chi-Square & 3963.092 \\
\cline { 2 - 3 } & Sf & 351 \\
\cline { 2 - 3 } & Sig. & .000 \\
\hline
\end{tabular}

As shown in Table 3, the KMO value of 0.866 was obtained which is $>0.5$ and is adequate while Bartlett's test significance value is $<0.05$, therefore, a null hypothesis is rejected. Hence, it was concluded that the sample is adequate for subsequent analyses and hypotheses testing.

\section{Research Instruments Reliability and Validity}

Hair et al. (2010) explained reliability as an examination of the degree of uniformity among multiple measurements of a variable. Nunnally (1994) suggests Cronbach's alpha value should exceed the values of 0.70 as consider a consistent and reliable questionnaire. The result is of the reliability test is shown in Table 4 . All constructs scored more than 0.700 hence it was confirmed that construct reliability has been achieved. 
Table 4Research Instrument Reliability

\begin{tabular}{ll}
\hline Construct/Dimension & $\begin{array}{l}\text { Cronbach's } \\
\text { Alpha }\end{array}$ \\
\hline Interactivity (INT) & 0.805 \\
Informativeness (INF) & 0.753 \\
Personalization (PER) & 0.736 \\
Trendiness (TRE) & 0.813 \\
Electronic Word of Mouth (EWM) & 0.757 \\
Consumer Perceived Trustworthiness (CPT) & 0.916 \\
\hline
\end{tabular}

The results of convergent validity indicators are shown in Table 5 . The factor loading ranged between 0.728 and 0.869 . A composite reliability score of more than 0.600 was reported. Finally, an average variance extracted value of at least 0.850 was achieved in the study. Based on these results, it was concluded that the measurement model in this study has obtained sufficient convergent validity and all items of the constructs were valid measures.

Table 5 Reliability and Validity for Constructs

\begin{tabular}{llll}
\hline Construct/Dimension & Item's & \multicolumn{2}{l}{ Composite } \\
& Loading & Reliability & AVE \\
\hline Interactivity (INT) & $0.833-0.869$ & 0.885 & 0.719 \\
Informativeness (INF) & $0.788-0.845$ & 0.858 & 0.668 \\
Personalization (PER) & $0.790-0.819$ & 0.850 & 0.654 \\
Trendiness (TRE) & $0.838-0.861$ & 0.889 & 0.728 \\
Electronic Word of Mouth (EWM) & $0.783-0.841$ & 0.861 & 0.673 \\
Consumer Perceived Trustworthiness (CPT) & $0.728-0.819$ & 0.931 & 0.600 \\
\hline
\end{tabular}

The results of discriminant validity are shown in Table 6. As shown, the square root of AVE (in bold) is well above inter-construct correlations (off-diagonal) for all constructs. Therefore, the Fornell-Larcker criterion was satisfied.

\begin{tabular}{|c|c|c|c|c|c|c|}
\hline & INF & INT & CPT & PER & TRE & EWM \\
\hline INF & 0.818 & & & & & \\
\hline INT & 0.540 & 0.848 & & & & \\
\hline CPT & 0.458 & 0.318 & 0.774 & & & \\
\hline PER & 0.562 & 0.433 & 0.514 & 0.809 & & \\
\hline TRE & 0.483 & 0.556 & 0.321 & 0.472 & 0.853 & \\
\hline EWM & 0.459 & 0.399 & 0.497 & 0.510 & 0.588 & 0.820 \\
\hline
\end{tabular}

Note: Values in the diagonal (bold) represent the square root of the AVE and the off-diagonal values exhibit the correlations.

Hypotheses Testing

Fulfillment of preliminary tests as discussed above allowed testing of hypotheses proposed in the research. Table 7 shows the results of the hypotheses testing. 
Table 7. Hypotheses Testing - Direct Relationships

\begin{tabular}{llll}
\hline & \multicolumn{2}{l}{ Standardized } & \\
Construct/Dimension & Beta & t-Value & p-Value \\
\hline Interactivity (INT) & 0.349 & 7.563 & 0.000 \\
Informativeness (INF) & 0.489 & 11.396 & 0.000 \\
Personalization (PER) & 0.557 & 13.634 & 0.000 \\
Trendiness (TRE) & 0.360 & 7.849 & 0.000 \\
Electronic Word of Mouth (EWM) & 0.532 & 12.759 & 0.000 \\
\hline
\end{tabular}

Dependent variable: Consumer Perceived Trustworthiness (CPT)

Results indicated that the $p$-value of all hypotheses tested was $<0.05$. This indicates that all hypotheses tested in the study were significant and therefore retained. Besides, the standardized beta value provided adequate evidence of a positive relationship between Interactivity, Informativeness, Personalization, Trendiness, Electronic Word of Mouth, and Consumer Perceived Trustworthiness. More importantly, Personalization and Electronic Word of Mouth were found to be stronger predictors of Consumer Perceived Trustworthiness.

\section{Discussion}

The results inferred there is a significant relationship established between social media advertising dimensions and consumer perceived trustworthiness. Hence, the study provided empirical evidence that the use of social media advertising would increase the consumer's perceived trustworthiness. This finding is in line with the previous study where Duffett (2015) reported that higher time spent on social media would result in more favorable behavioral attitudes towards social media advertising. These findings have also strengthened premises advocated by Credibility Theory attractiveness would increase trustworthiness (Phung \& Qin, 2018). This was affirmed by Lafferty and Goldsmith (1999) who discovered that credibility is an important factor that influences the genesis of attitude and behavior towards advertising which supports the relationship between Social Media Advertising and Consumer Perceived Trustworthiness. Interactivity can reflect the ability to control, communication in both directions, and synchronicity (Liu \& Shrum, 2002). This is also referring to the degree of freedom where the user can manipulate the content and presented information (BezjianAvery et al., 1998). For example, high control can be a social media platform, whereas low control can be traditional TV. Whereas high control can let the users freely choose what and how to read the content, high control provides consumers more chances to seek the related information in an active manner (Wang et al., 2012).

Information was also found to influence the level of trustworthiness among the consumers. This was evident in the research since a positive association was found between informativeness and consumer perceived trustworthiness. Shareef et al. (2019) concurred with this finding and further explained that informativeness plays an important role to create consumers' positive perceptions towards the advertisement regardless of traditional or online advertisement. Personalization is the highest predictor of customer perceived trustworthiness in the research. This is mainly because the social media content that is filtered toward user preference will lead to higher satisfaction and better user engagement (Erat et al., 2006). On the other hand, the quality of social interaction is the key factor that drives higher user engagement, instead of the content shared frequency (Prahalad \& Ramaswamy, 2004). In brief, if a personalized user experience is made, users will notice their role as more important 
and related, and it creates a more fulfilling experience toward the site (Di Gangi \& Wasko, 2016), therefore informativeness would increase the consumer perceived trustworthiness which strongly supports the relationship between social media advertising and consumer perceived trustworthiness. Godey et al. (2016) posit that trendiness is the propagation or spread of the latest and trendiness information. Auty and Elliott (1998) added that younger people were likely to be viewed as trendy. The significant positive association between electronic word of mouth and consumer perceived trustworthiness was also evident in the previous researches where Yunus et al. (2016) found that the eWoM is positively affecting the consumers' perceived social media trustworthiness.

\section{Conclusion}

Social media advertising is becoming one of the major advertising channels today, as such by understanding and identified the dominant factor that influences consumer perceived trustworthiness becomes vital for delivering effective advertising with trustworthiness being the key driver that influences customers (Hee \& Yen, 2018). The study has contributed theoretically by providing additional insights in explaining consumer behaviors toward social media advertising. Additionally, it has provided insights about the dominant dimension that is affecting and contributing to the customer's perceived trustworthiness, which was evident through the standardized beta, values reported. From a practical implications perspective, this study provided some directions for the advertising industry to prepare for the advertising revolution, as people start shifting from traditional advertising to the social media advertising channel. People are now are spending more time on social media platforms. This study would allow the advertiser to understand social media users' behaviors. Thus, this study will help social media advertising in general and the food and beverage industry, in particular, to look into dominant factors that create consumer trustworthiness while designing their social media marketing interventions to maximize the effect of advertising. This would ultimately lead to stronger survival in a fast-changing and competitive business environment.

\section{References}

Ajina, A. S. (2019). The perceived value of social media marketing: An empirical study of online word-of-mouth in Saudi Arabian context. Entrepreneurship and Sustainability Issues, 6(3), 1512.

Algharabat, R., Rana, N. P., Dwivedi, Y. K., Alalwan, A. A., \& Qasem, Z. (2018). The effect of telepresence, social presence and involvement on consumer brand engagement: An empirical study of non-profit organizations. Journal of retailing and consumer services, 40, 139-149.

Ali Taha, V., Pencarelli, T., Škerháková, V., Fedorko, R., \& Košíková, M. (2021). The Use of Social Media and Its Impact on Shopping Behavior of Slovak and Italian Consumers during COVID-19 Pandemic. Sustainability, 13(4), 1710.

Ariel, Y., \& Avidar, R. (2015). Information, interactivity, and social media. Atlantic Journal of Communication, 23(1), 19-30.

Arnold, A. (2018). Consumer Trust In Social Media Is Declining: Here's How Brands Should Change Their Strategies. Forbes Magazine.

Auty, S., \& Elliott, R. (1998). Fashion involvement, self-monitoring and the meaning of brands. Journal of Product \& Brand Management. 
Balaban, D., \& Mustățea, M. (2019). Users' perspective on the credibility of social media influencers in Romania and Germany. Romanian Journal of Communication and Public Relations, 21(1), 31-46.

Bartlett, M. S. (1950). Tests of significance in factor analysis. British Journal of statistical psychology, 3(2), 77-85.

Bermoy, N. N. B., De Guzman, J. J. J., De Guzman, J. L., Vega, S. K. P. D., Hernandez Jr, L., Ignacio, M. T. B., Templado, S. M., \& Trinidad, A. O. (2021). Influence of Social Media as a Marketing Platforms for Food-related Products in the New Normal. International Journal of Multidisciplinary Studies, 5(5), 106-111.

Bezjian-Avery, A., Calder, B., \& lacobucci, D. (1998). New media interactive advertising vs. traditional advertising. Journal of advertising research, 38, 23-32.

Burton, L. J., \& Mazerolle, S. M. (2011). Survey instrument validity part I: Principles of survey instrument development and validation in athletic training education research. Athletic Training Education Journal, 6(1), 27-35.

Büttner, O. B., \& Göritz, A. S. (2008). Perceived trustworthiness of online shops. Journal of Consumer Behaviour: An International Research Review, 7(1), 35-50.

Chu, S.-C., \& Kim, Y. (2011). Determinants of consumer engagement in electronic word-ofmouth (eWOM) in social networking sites. International Journal of Advertising, 30(1), 47-75.

Corkindale, D., Ram, J., \& Chen, H. (2018). The adoption of firm-hosted online communities: an empirical investigation into the role of service quality and social interactions. Enterprise Information Systems, 12(2), 173-195.

Di Gangi, P. M., \& Wasko, M. M. (2016). Social media engagement theory: Exploring the influence of user engagement on social media usage. Journal of Organizational and End User Computing (JOEUC), 28(2), 53-73.

Dolan, R., Conduit, J., Fahy, J., \& Goodman, S. (2016). Social media engagement behaviour: a uses and gratifications perspective. Journal of Strategic Marketing, 24(3-4), 261-277.

Downes, E. J., \& McMillan, S. J. (2000). Defining interactivity: A qualitative identification of key dimensions. New media \& society, 2(2), 157-179.

Duffett, R. G. (2015). Facebook advertising's influence on intention-to-purchase and purchase amongst Millennials. Internet Research.

Erat, P., Desouza, K. C., Schäfer-Jugel, A., \& Kurzawa, M. (2006). Business customer communities and knowledge sharing: exploratory study of critical issues. European Journal of Information Systems, 15(5), 511-524.

Erdem, T., \& Swait, J. (2004). Brand credibility, brand consideration, and choice. Journal of Consumer Research, 31(1), 191-198.

Ertmer, P. A., \& Newby, T. J. (1993). Behaviorism, cognitivism, constructivism: Comparing critical features from an instructional design perspective. Performance improvement quarterly, 6(4), 50-72.

Estrella-Ramón, A., \& Ellis-Chadwick, F. (2017). Do different kinds of user-generated content in online brand communities really work? Online Information Review.

Godey, B., Manthiou, A., Pederzoli, D., Rokka, J., Aiello, G., Donvito, R., \& Singh, R. (2016). Social media marketing efforts of luxury brands: Influence on brand equity and consumer behavior. Journal of Business Research, 69(12), 5833-5841.

Goldfarb, A., \& Tucker, C. (2013). Why managing consumer privacy can be an opportunity. MIT Sloan Management Review, 54(3), 10. 
Goodwin, C. (1996). Communality as a dimension of service relationships. Journal of Consumer Psychology, 5(4), 387-415.

Gupta, R. C., \& Maheshwari, S. (2021). MEDIA ADVERTISING AND IMPACT ON SOCIAL AND CULTURAL ELEMENTS. Journal of Organizational Culture, Communications and Conflict, 25(1), 1-3.

Hadija, Z. (2008). Perceptions of advertising in online social networks: In-depth interviews.

Hair, J., Anderson, R. E., Tatham, R. L., \& Black, W. C. (1998). Multivariate data analysis. New Jersey. Prentice-Hall. Hu Q., Huang CD (2006)," Using the balanced scorecard to achieve sustained IT-business alignment: A case study", Communications of the Association for Information Systems, 17, 181-204.

Hair, J., Black, W., Babin, B., Anderson, R., \& Tatham, R. (2010). Multivariate Data Analysis New Jersey: Pearson Prentice Hall. Alih bahasa: Soleh Rusyadi Maryam. Jilid, 2.

Hassan, M. U., Fatima, S., Akram, A., Abbas, J., \& Hasnain, A. (2013). Determinants of consumer attitude towards social-networking sites advertisement: Testing the mediating role of advertising value. Middle-east journal of scientific research, 16(3), 319330.

Hee, O. C., \& Yen, W. S. (2018). The Influence of advertising media towards consumer purchasing behavior in the food and beverage industry in Malaysia. International Journal of Human Resource Studies, 8(2), 148-163.

Hossain, M. A. (2019). Effects of uses and gratifications on social media use. PSU Research Review.

Hutter, K., Hautz, J., Dennhardt, S., \& Füller, J. (2013). The impact of user interactions in social media on brand awareness and purchase intention: the case of MINI on Facebook. Journal of Product \& Brand Management.

Jarvenpaa, S. L., Tractinsky, N., \& Vitale, M. (2000). Consumer trust in an Internet store. Information technology and management, 1(1), 45-71.

Jiang, G., Liu, F., Liu, W., Liu, S., Chen, Y., \& Xu, D. (2021). Effects of information quality on information adoption on social media review platforms: Moderating role of perceived risk. Data Science and Management, 1(1), 13-22.

Kaiser, H. F. (1960). The application of electronic computers to factor analysis. Educational and psychological measurement, 20(1), 141-151.

Kaplan, A. M., \& Haenlein, M. (2010). Users of the world, unite! The challenges and opportunities of Social Media. Business Horizons, 53(1), 59-68.

Kapoor, K. K., Tamilmani, K., Rana, N. P., Patil, P., Dwivedi, Y. K., \& Nerur, S. (2018). Advances in social media research: Past, present and future. Information Systems Frontiers, 20(3), 531-558.

Kaur, P., Dhir, A., Rajala, R., \& Dwivedi, Y. (2018). Why people use online social media brand communities: A consumption value theory perspective. Online Information Review.

Kelly, L., Kerr, G., \& Drennan, J. (2010). Avoidance of advertising in social networking sites: The teenage perspective. Journal of interactive advertising, 10(2), 16-27.

Kettinger, W. J., \& Lee, C. C. (1994). Perceived service quality and user satisfaction with the information services function. Decision Sciences, 25(5-6), 737-766.

Kim, A. J., \& Ko, E. (2010). Impacts of luxury fashion brand's social media marketing on customer relationship and purchase intention. Journal of Global Fashion Marketing, 1(3), 164-171.

Knoll, J. (2016). Advertising in social media: a review of empirical evidence. International Journal of Advertising, 35(2), 266-300. 
Kothari, M., Nanda, J., \& Hari, L. (1997). Selection of sampling period for automatic generation control. Electric machines and power systems, 25(10), 1063-1077.

Kowang, T. O., Jonid, N. A. B., Yew, L. K., Fei, G. C., \& Hee, O. C. (2018). Youngsters Perception Toward Social Networking Advertising: Does Social Media Advertising Factors Still Matter.

Kumar, V., \& Pradhan, P. (2018). Trust management issues in social-media marketing. In Social Media Marketing: Breakthroughs in Research and Practice (pp. 714-732). IGI Global.

Lafferty, B. A., \& Goldsmith, R. E. (1999). Corporate credibility's role in consumers' attitudes and purchase intentions when a high versus a low credibility endorser is used in the ad. Journal of Business Research, 44(2), 109-116.

Lakshmanan, D., \& Basariya, S. R. (2017). The Role of Social Media on Enhancing Advertising Effectiveness. International Journal of Civil Engineering and Technology (IJCIET), 8(9), 1042-1047.

Lal, B., Ismagilova, E., Dwivedi, Y. K., \& Kwayu, S. (2020). Return on Investment in Social Media Marketing: Literature Review and Suggestions for Future Research. Digital and Social Media Marketing, 3-17.

Lewicki, R. J., Tomlinson, E. C., \& Gillespie, N. (2006). Models of interpersonal trust development: Theoretical approaches, empirical evidence, and future directions. Journal of Management, 32(6), 991-1022.

Lim, X. J., Radzol, A., Cheah, J., \& Wong, M. W. (2017). The impact of social media influencers on purchase intention and the mediation effect of customer attitude. Asian Journal of Business Research, 7(2), 19-36.

Liu, Y., \& Shrum, L. J. (2002). What is interactivity and is it always such a good thing? Implications of definition, person, and situation for the influence of interactivity on advertising effectiveness. Journal of advertising, 31(4), 53-64.

Luna-Nevarez, C., \& Torres, I. M. (2015). Consumer attitudes toward social network advertising. Journal of Current Issues \& Research in Advertising, 36(1), 1-19.

Mangold, W. G., \& Faulds, D. J. (2009). Social media: The new hybrid element of the promotion mix. Business Horizons, 52(4), 357-365.

Mayer, R. C., Davis, J. H., \& Schoorman, F. D. (1995). An integrative model of organizational trust. Academy of management review, 20(3), 709-734.

McCole, P., Ramsey, E., \& Williams, J. (2010). Trust considerations on attitudes towards online purchasing: The moderating effect of privacy and security concerns. Journal of Business Research, 63(9-10), 1018-1024.

McKnight, D. H., Cummings, L. L., \& Chervany, N. L. (1998). Initial trust formation in new organizational relationships. Academy of management review, 23(3), 473-490.

Meskaran, F. (2015). The Effect of Perceived Trust, Perceived Security and Attitude on Online Purchase Intention in Malaysia Public Universities Universiti Teknologi Malaysia].

Mir, I. A. (2012). Consumer attitudinal insights about social media advertising: A South Asian perspective. The Romanian Economic Journal, 15(45), 265-288.

Mishra, A. S. (2019). Antecedents of consumers' engagement with brand-related content on social media. Marketing Intelligence \& Planning.

Mittal, B., \& Lassar, W. M. (1996). The role of personalization in service encounters. Journal of retailing, 72(1), 95-109.

Muntinga, D. G., Moorman, M., \& Smit, E. G. (2011). Introducing COBRAs: Exploring motivations for brand-related social media use. International Journal of Advertising, 30(1), 13-46. 
Naaman, M., Becker, H., \& Gravano, L. (2011). Hip and trendy: Characterizing emerging trends on Twitter. Journal of the American Society for Information Science and Technology, 62(5), 902-918.

Newhagen, J. E., \& Rafaeli, S. (1996). Why communication researchers should study the Internet: A dialogue. Journal of Computer-Mediated Communication, 1(4), JCMC145.

Nicosia, F. M. (1966). Consumer Decision Processes; Marketing and Advertising Implications.

Nunnally, J. C. (1994). Psychometric theory 3E. Tata McGraw-hill education.

Nwagwu, W. E., \& Famiyesin, B. (2016). Acceptance of mobile advertising by consumers in public service institutions in Lagos, Nigeria. The Electronic Library.

Ohanian, R. (1991). The impact of celebrity spokespersons' perceived image on consumers' intention to purchase. Journal of advertising research.

Parasuraman, A., Berry, L. L., \& Zeithaml, V. A. (1991). Understanding customer expectations of service. Sloan management review, 32(3), 39-48.

Pham, P. H., \& Gammoh, B. S. (2015). Characteristics of social-media marketing strategy and customer-based brand equity outcomes: A conceptual model. International Journal of Internet Marketing and Advertising, 9(4), 321-337.

Phung, L., \& Qin, L. (2018). Perception of social media influencers: A study on evaluation of Social Media Influencer types for different beauty categories. In.

Plume, C. J., \& Slade, E. L. (2018). Sharing of sponsored advertisements on social media: A uses and gratifications perspective. Information Systems Frontiers, 20(3), 471-483.

Prahalad, C. K., \& Ramaswamy, V. (2004). Co-creation experiences: The next practice in value creation. Journal of interactive marketing, 18(3), 5-14.

Samat, M. F., Hashim, H., \& Yusoff, R. N. R. (2014). Endorser credibility and its influence on the attitude toward social media advertisement in Malaysia. Review of Integrative Business \& Economics, 4(1), 144-159.

Shareef, M. A., Mukerji, B., Dwivedi, Y. K., Rana, N. P., \& Islam, R. (2019). Social media marketing: Comparative effect of advertisement sources. Journal of retailing and consumer services, 46, 58-69.

Shiau, W.-L., Dwivedi, Y. K., \& Yang, H. S. (2017). Co-citation and cluster analyses of extant literature on social networks. International Journal of Information Management, 37(5), 390-399.

Stephen, A. T., \& Lehmann, D. R. (2016). How word-of-mouth transmission encouragement affects consumers' transmission decisions, receiver selection, and diffusion speed. International Journal of Research in Marketing, 33(4), 755-766.

Susanto, H., Yie, F. L., Mohiddin, F., Setiawan, R. A. A., Haghi, P. K., \& Setiana, D. (2021). Revealing Social Media Phenomenon in Time of COVID-19 Pandemic for Boosting StartUp Businesses through Digital Ecosystem. Applied System Innovation, 4(1), 6.

Thongsri, N., Shen, L., Bao, Y., \& Alharbi, I. M. (2018). Integrating UTAUT and UGT to explain behavioural intention to use M-learning: A developing country's perspective. Journal of Systems and Information Technology.

Toscan, C. (1999). A New Generation of Audiences for the 21st Century. InteractiveTelevision. TV of the Future or the Future of TV, 261-278.

Vollmer, C., \& Precourt, G. (2008). Always on: Advertising, marketing, and media in an era of consumer control. McGraw Hill Professional.

Wang, Y.-T., Wu, L.-L., Chen, H.-C., \& Yeh, M.-Y. (2012). Interactivity of social media and online consumer behavior: The moderating effects of opinion leadership. 
Wang, Y., Min, Q., \& Han, S. (2016). Understanding the effects of trust and risk on individual behavior toward social media platforms: A meta-analysis of the empirical evidence. Computers in Human Behavior, 56, 34-44.

Wijenayake, S., Hettiachchi, D., Hosio, S. J., Kostakos, V., \& Goncalves, J. (2020). Effect of Conformity on Perceived Trustworthiness of News in Social Media. IEEE Internet Computing.

Xiao, M., Wang, R., \& Chan-Olmsted, S. (2018). Factors affecting YouTube influencer marketing credibility: a heuristic-systematic model. Journal of media business studies, 15(3), 188213.

Xu-Priour, D.-L., Truong, Y., \& Klink, R. R. (2014). The effects of collectivism and polychronic time orientation on online social interaction and shopping behavior: A comparative study between China and France. Technological Forecasting and Social Change, 88, 265275.

Yaakop, A., Anuar, M. M., \& Omar, K. (2013). Like it or not: Issue of credibility in Facebook advertising. Asian Social Science, 9(3), 154.

Yadav, M., \& Rahman, Z. (2018). The influence of social media marketing activities on customer loyalty: A study of e-commerce industry. Benchmarking: An International Journal.

Yunus, N. H., Md Ariff, M. S., Mohd Som, N., Zakuan, N., \& Sulaiman, Z. (2016). The mediating effect of brand image between electronic word of mouth and purchase intention in social media. Advanced Science Letters, 22(10), 3176-3180.

Zong, W., Yang, J., \& Bao, Z. (2019). Social network fatigue affecting continuance intention of social networking services. Data Technologies and Applications. 